\title{
The Productivity and Nutritive Value of Imperata cylindrica (L) Beauv. in the Thai Highlands
}

\author{
J. LINDSAY FALVEY, PRAKOB HENGMICHAI, AND PUNTIPA PONGPIACHAN
}

\section{Abstract}

The rate of dry matter production after the annual pre-wet season burning, the rate of regrowth after cutting at three times during the year and the nitrogen content, phosphorus content and in vitro digestibility of Imperata cylindrica were studied in highlands of north Thailand over a one-year period. Dry matter production was slower than that recorded in more tropical regions and nitrogen content and digestibility correspondingly remained higher for longer. It is suggested that the slower growth rates recorded in this environment, permitted Imperata to remain a useful forage for a longer period than is usually considered possible for this species.

Imperata cylindrica, an upright rhizomatous grass with no obvious stem, is widespread throughout the tropics and subtropics and it is estimated that approximately 200 million of the 500 million hectares in the world is in southeast Asia (Martoatmodjo 1976). Imperata is the predominant native pasture species in the highlands of north Thailand where it represents a fire climax vegetation created by the burning associated with shifting cultivation that covers an estimated 2,500 square kilometres (Gibson and Van Diepenl 1977). The growth of Imperata in the moderated tropical monsoonal climate of this region is probably slower than generally acknowledged for this species and a lower degree of vigor is indicated from the relative instability of Imperata dominant areas under moderate stocking rates (Falvey and Hengmichai 1979).

Imperata is largely considered to be an undesirable species due to its inflammability and poor nutritional quality and has therefore been the subject of only limited research. Holmes et al. (1976) have noted the value of Imperata as a natural pasture in New Guinea, as have Magadan et al. (1974) in the Phillipines and Soewardi and Sastradiprodja (1975) in Indonesia. There have, however, been no studies reported on the growth and quality of Imperata growing in less tropical areas.

This study aimed to define the productivity and quality of Imperata in the highlands of north Thailand in order to assist in the understanding of the nutrition of cattle in this region.

\section{Methods}

The experiment was conducted at the research site of the Thai Australian Highland Agricultural Project, which is located north of Chiang Mai $\left(19^{\circ} \mathrm{N}, 99^{\circ} \mathrm{E}\right)$, Thailand, at an altitude of 1,500 metres. The climate of the area is tropical monsoon modified by altitude, with a mean annual rainfall of $1,630 \mathrm{~mm}, 90 \%$ of which falls within the 6-month period from May to October.

A monospecific sward of Imperata cylindrica (L) Beauv. was burned on March 23, 1978, as part of the annual wildfires common to this region. The area was excluded from grazing and a total of

Authors are animal nutritionist, Department of Agriculture, University of Queensland, Australia; animal nutritionist, Tribal Research Centre, Chiang Mai University, Thailand; and lecturer, Faculty of Agriculture, Chiang Mai University, Thailand. Manuscript received October 15, 1979.
$52,2 \times 1$-metre plots were marked out in four replicates. During the wet season, from April to October, four plots were harvested $\left(1 \mathrm{~m}^{2}\right)$ to a height of $1 \mathrm{~cm}$ above ground level every 3 weeks. The small fraction of dead leaves was discarded from all samples. During the dry season, three cuts of green leaf material were made. After harvesting, the whole plot was cut to one centimetre above ground level and the cut material removed from the experimental area. On the dates July 11, 1978; November 14, 1978; and March 14 , 1979, green leaves from all plots that had previously been harvested were reharvested.

Individual samples were oven dried at $72^{\circ} \mathrm{C}$ and weighed. Sampled replicates were then composited and after grinding to pass through a $1 \cdot \mathrm{mm}$ sieve were analyzed for nitrogen and phosphorus contents. In vitro digestibility analysis of these samples was also performed using a pepsin-cellulase technique based on that of Goto and Minson (1979). The technique varied in two respects: centrifuging speed was at $2,000 \mathrm{rpm}$ for 30 minutes, and washing of samples after digestion was conducted twice. An area of Imperata that had remained unburned and ungrazed for a period of 5 years was also harvested once on November 28, 1978, and the same data collected. Dead leaves were discarded.

\section{Results}

The mean cumulative dry matter production of Imperata over 1 year is presented in Figure 1, together with nitrogen and phosphorus contents and the in vitro digestibility values of the harvested samples. Mean dry matter production reached a peak of 3,919 $\mathrm{kg} \mathrm{ha}^{-1}$ in January, although little additional growth was recorded after the end of the wet season (October). The mean dry matter production of the 5-year old sward was $4,192 \mathrm{~kg} \mathrm{ha}^{-1}$.

Nitrogen content of the harvested samples declined from 2.93 to 0.56 (\% in d.m.) while phosphorus content declined from 0.37 to 0.90 (\% in d.m.). The in vitro digestibility declined from $71.4 \%$. Nitrogen, phosphorus, and in vitro digestibility values for the 5 -year old sward were $0.66 \%, 0.12 \%$, and $31.4 \%$, respectively.

The dry matter production of plots reharvested for the first time on the date July 11, 1978; November 14, 1978; and March 14, 1979, is presented in Figure 2 together with data for the nitrogen and phosphorus contents and in vitro digestibility. The rate of regrowth appeared to be highest for plots harvested on November 14,1978 , while nitrogen, phosphorus and to a lesser extent in vitro digestibility values were highest for early wet season regrowth (July 11,1978 ) and lowest for dry season regrowth (March 14, 1979).

Dry matter production to November 14,1978 , for plots reharvested for the second time varied from 461 to $743 \mathrm{~kg}^{-h^{-1}}$ for the 126-day regrowth period. There was a slight tendency for the plots that had undergone longer first regrowth periods to produce more in this second regrowth period. Nitrogen contents varied from 1.01 to $1.11 \%$ in d.m., phosphorus contents from $0.14-0.15 \%$ in d.m. and in vitro digestibility from $42.0 \%$ to $49.8 \%$.

Dry matter production to March 14, 1979, for plots reharvested for the second time was lower than that of comparable plots that regrew during the wet season (to November 14, 1978). Values 

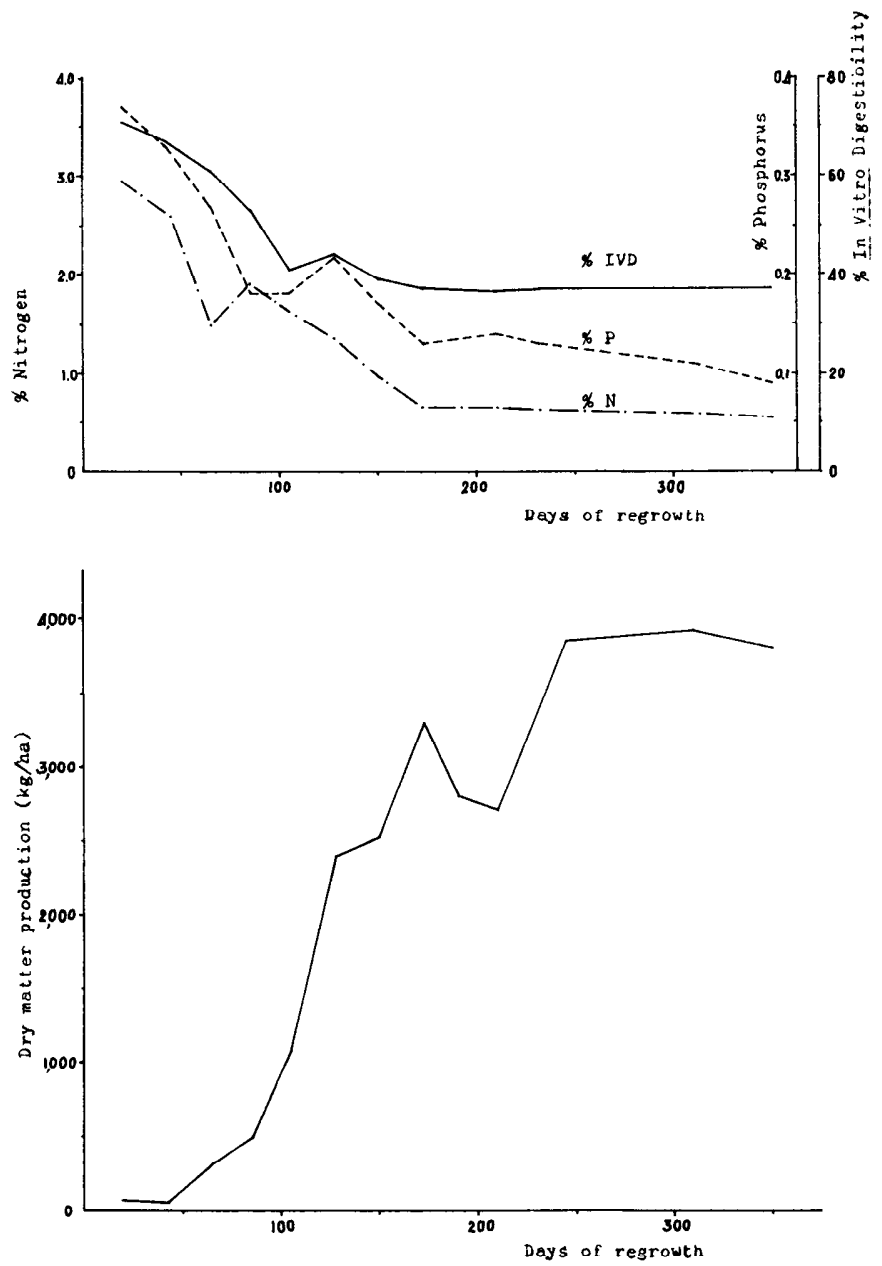

Fig. 1. Cumulative dry matter production, nitrogen content, phosphorus content, and in vitro digestibility of Imperata cylindrica over 1 year.

ranged from $207 \mathrm{ka} \mathrm{ha}^{-1}$ for the 120-day regrowth period. Nitrogen content varied from 0.72 to $1.08 \%$ in d.m., phosphorus content varied from 0.9 to $0.13 \%$ in $\mathrm{d} . \mathrm{m}$. and in vitro digestibility from $40.4 \%$ to 45.6 . For those plots that were reharvested for the third time at this date, dry matter production varied from 207 to 552 ${\mathrm{kg} \cdot \mathrm{ha}^{-1}}^{-1}$, nitrogen contents from 0.80 to $1.26 \%$ in d.m., phosphorus contents from 0.10 to $0.13 \%$ in d.m., and in vitro digestibility from $38.1 \%$ to $44.8 \%$.

\section{Discussion}

The rate of dry matter production of Imperata in this region was lower than in other regions while the rate of decline in nitrogen was slower; for example, in New Guinea (Holmes et al. 1975), cutting at 12 weeks produced a mean of $320 \mathrm{~kg} \mathrm{~d} . \mathrm{m}$. week $^{-1}$ of $0.93 \%$ nitrogen content compared with $42 \mathrm{~kg} \mathrm{d.m}$. week ${ }^{-1}$ of approximately $1.90 \%$ nitrogen content in this study. Indeed, the highest cutting frequency in the New Guinea study of 4 weeks produced a mean of 152 $\mathrm{kg} \mathrm{d.m}$. week ${ }^{-1}$ compared to $20 \mathrm{~kg} \mathrm{d.m}$. week ${ }^{-1}$ for this study, while the nitrogen contents were $1.48 \%$ and $2.90 \%$, respectively.

This slower rate of growth and associated slower rate of decline in nitrogen content potentially increases the value of Imperata as a native range species, provided that dry matter production is sufficiently high to allow reasonable levels of intake. If a level of $1.1 \%$ nitrogen is accepted as a critical level for liveweight gains in steers (Milford 1960; Milford and Haydock 1965), the Imperata pasture in New Guinea would need to be cut every 6 weeks, which is not usually possible in free range management systems. In the highlands of Thailand, however, nitrogen values are above this critical level for about 20 weeks.

Regrowth during the early wet season after the first cuttings
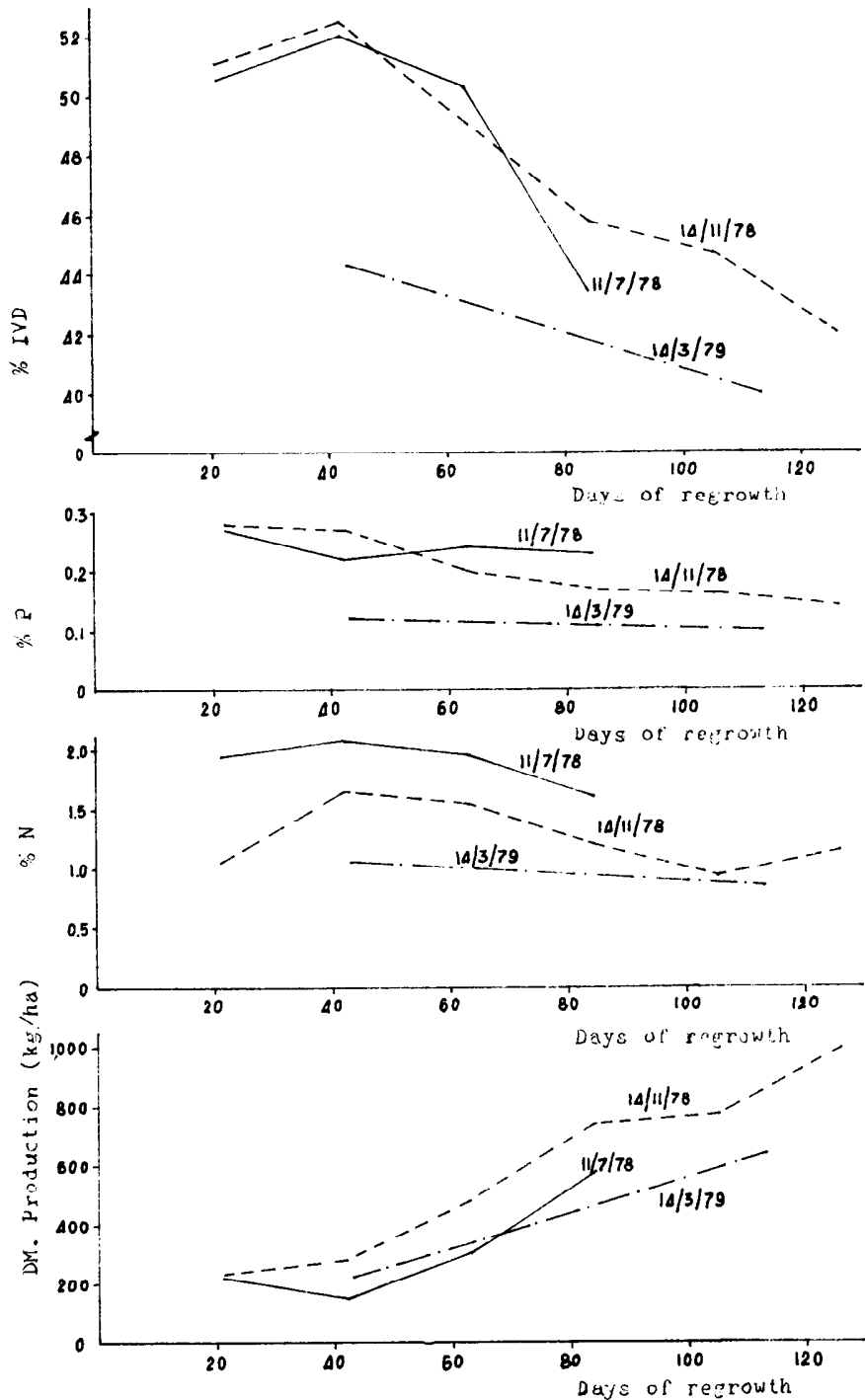

Fig. 2. Dry matter production of regrowth, nitrogen content, phosphorus content, and in vitro digestibility of Imperata cylindrica harvested at three dates.

produced forage with nitrogen contents above 1.1\%; however, regrowth during the late wet season was above this level only for a period of approximately 5 weeks, and dry season regrowth was always below this level. Regrowth after the second and third cuttings showed similar nitrogen contents.

The reduced rates of growth of Imperata would, however, mean that stocking rates must be lower than those recorded in New Guinea (Holmes et al. 1974). The Phillipines (Magadan et al. 1974) and Indonesia (Soewardi and Sastradipradja 1976), which are $0.61-1.29,1.0$ and 0.2 beasts $^{-1} a^{-1}$, respectively. Estimates of stocking rate in the Thai highlands vary from 0.14 to 0.04 beast $\cdot$ ha-1 (Falvey 1976). Phosphorus contents were above the suggested critical level for nonlactating stock of $0.18 \%$ (Cohen 1975) for similar periods that the nitrogen levels exceeded $1.1 \%$. Thus any phosphorus deficiency in cattle grazing these pastures may be masked by a primary nitrogen deficiency.

The in vitro digestibilities recorded in this experiment are within the range common for tropical species (Minson and McLeo 1970). The rate of intake of Imperata may be restricted by the low digestibility of the herbage after several weeks growth. Comparative data from elsewhere are lacking; nevertheless, the digestibility of the herbage appears to show similar a trend to that of nitrogen content in that the rate of decline appears slower than is commonly expected in the more tropical areas. This may be related to the effect of temperature on digestibility reported by Minson and McLeod (1970). 
It therefore seems likely that free range cattle grazing on growing and regrowing Imperata from soon after burning and throughout the wet season and perhaps the early dry scason can be consuming an above-maintenance diet. A preliminary study of the liveweight gains of cattle grazing such pastures supports this thesis (Falvey et al. 1979).

\section{Literature Cited}

Cohen, R.D.H. 1975. Phosphorus for grazing beef cattle. Aust. Meat Res. Comm. Rev. 23:1-16.

Falvey, L. 1976. Ruminants in the highlands of Northern Thailand-an agrosociological study. 124 p. Aust. Dev. Assis. Bur., Canberra.

Falvey, L., P. Hengmichai, and P. Hoare. 1979. Productivity of cattle grazing native highland pastures. Thai J. Agr. Sci. 12:61-69.

Falvey, L., and P. Hengmichai. 1979. Invasion of Imperata cylindrica (L) Beauv. by Eupatorium species. J. Range Manage. 32:340-344.

Gibson, T.A., and D. Van Diepen. 1977. The area under grassland in northern Thailand. Report of the U.N. Prog. Drug Abuse Control, Chiang Mai, Thailand (mimeo).

Goto, I., and D.J. Minson. 1977. Prediction of the dry matter digestibility of tropical grasses using a pepsin-cellulase assay. Anim. Feed Sci. Tech. 2:247-253.
Holmes, J.H.G., C. Lemerte, and J.H. Schottler. 1976. Imperata cylindrica for cattle production in Papua New Guinea. BIOTROP Workshop on alang-alang (Imperata cylindrica), July 27-29, 1976, Bogor, Indonesia.

Magadan, P.B., E.Q. Javier, and J.C. Madamba. 1974. Beef production on native (Imperata cylindrica) (L) Beauv) and Para grass (Brachiaria mutica (Forsk) Stapf.) pastures in the Philippines. Proc. 12th Internat. Grassland Cong., Moscow 1974. p. 370-378.

Martoamodjo, R.S. 1976. A leaflet distributed to participants of the BIOTROP workshop on alang-alang (Imperata cylindrica), July 27-29, 1976, Bogor, Indonesia.

Milford, R. 1960. Criteria for expressing nutritional values of subtropical grasses. Aust. J. Agr. Res. 11:121-137.

Milford, R., and K.P. Haydock. 1965. The nutritive value of protein in subtropical pasture species grown in south-east Queensland. Aust. J. Exp. Agr. Anim. Husb. 5:13-17.

Minson, D.J., and M.N. McLeod. 1970. The digestibility of temperate and tropical grasses. Proc. 11th Internat. Grassland Cong. p. 719-722.

Soewardi, B., D. Sastradipraja, A.H. Nasation, and J.H. Hutasoit, 1975. The influence of corn and cassava meal supplementation on the feeding value of alang-alang (Imperata cylindrica (L.) Beauv.) for Ongole grade heifers. Malaysian J. Agr. Res. 4:123-130. 